\title{
Resistance of Malus domestica Fruit to Botrytis cinerea Depends on Endogenous Ethylene Biosynthesis
}

\author{
Aya Akagi, Abhaya M. Dandekar, and Henrik U. Stotz
}

First and third authors: Department of Horticulture, 4017 Agriculture \& Life Sciences Bldg., Oregon State University, Corvallis 97331; and second author: Department of Plant Sciences, 152 Robbins Hall, University of California, Davis 95616.

Current address for A. Akagi: Disease Resistant Crops Research Unit, GMO Research Center, National Institute of Agrobiological Science, Tsukuba, Ibaraki 305-8602, Japan.

Current address for H. U. Stotz: Julius-von-Sachs-Institute fuer Biowissenschaften, Pharmazeutische Biologie, Universitaet Wuerzburg, 97082 Wuerzburg, Germany.

Accepted for publication 16 June 2011.

\begin{abstract}
Akagi, A. Dandekar, A. M., and Stotz, H. U. 2011. Resistance of Malus domestica fruit to Botrytis cinerea depends on endogenous ethylene biosynthesis. Phytopathology 101:1311-1321.

The plant hormone ethylene regulates fruit ripening, other developmental processes, and a subset of defense responses. Here, we show that 1-aminocyclopropane-1-carboxylic acid synthase (ACS)-silenced apple (Malus domestica) fruit that express a sense construct of ACS were more susceptible to Botrytis cinerea than untransformed apple, demonstrating that ethylene strengthens fruit resistance to $B$. cinerea infection. Because ethylene response factors (ERFs) are known to contribute to resistance

against $B$. cinerea via the ethylene-signaling pathway, we cloned four ERF cDNAs from fruit of $M$. domestica: $M d E R F 3,-4,-5$, and -6. Expression of all four MdERF mRNAs was ethylene dependent and induced by wounding or by $B$. cinerea infection. $B$. cinerea infection suppressed rapid induction of wound-related MdERF expression. MdERF3 was the only mRNA induced by wounding and $B$. cinerea infection in ACSsuppressed apple fruit, although its induction was reduced compared with wild-type apple. Promoter regions of all four MdERF genes were cloned and putative cis-elements were identified in each promoter. Transient expression of MdERF3 in tobacco increased expression of the GCC-box containing gene chitinase 48.
\end{abstract}

The plant hormone ethylene is involved in many plant developmental processes such as fruit ripening, seed germination, senescence, abscission, and epinasty. Ethylene is also induced by biotic and abiotic stimuli, including wounding (74). Ethylene response factors (ERFs) are transcription factors (TFs) that affect various environmental responses and developmental processes. They act downstream of plant hormones to regulate ethylene, jasmonate, abscisic acid, and the cytokinin-signaling pathways. ERFs mediate plant development $(52,70)$ and control environmental stress responses to cold, dehydration, and salinity $(8,23,46,54,57,59$, 64,66,75-78).

AP2/ERF proteins are members of the second-largest superfamily of TFs in Arabidopsis thaliana (56). This superfamily was believed to be plant specific but the AP2/ERF domain is also present in the cyanobacterium Trichodesmium erythraeum, the ciliate Tetrahymena thermophila, and the viruses Enterobacteria phage Rb49 and Bacteriophage Felix 01 (40). The 122 Arabidopsis and 139 rice $E R F$ genes have been classified into 12 and 15 subfamilies, respectively, based on structural similarities of AP2/ERF domain sequences and conserved motifs outside the DNA-binding domain (46). ERF genes encode one AP2/ERF domain composed of three $\beta$-sheets and one $\alpha$-helix; the $\beta$-sheets interact with the GCC-box motif in the target DNA (3). Although the functions of a few $A$. thaliana ERFs, here referred to as

Corresponding author; A. M. Dandekar; E-mail address: amdandekar@ucdavis.edu

* The $\boldsymbol{e}$-Xtra logo stands for "electronic extra" and indicates that the online version contains four supplementary figures and one supplementary table.

doi:10.1094/PHYTO-03-11-0087

(c) 2011 The American Phytopathological Society
AtERFs, have been analyzed, information about the function of most ERF subfamilies is limited.

Ethylene activates different sets of target genes depending on the specific developmental, abiotic, or biotic signal. The posttranslationally regulated TF AtEIN3 indirectly induces defenserelated genes via transcriptional activation of AtERF1. In turn, AtERF1 interacts with the GCC-box motif in promoter regions of ethylene-regulated defense genes in Arabidopsis (63). On the other hand, AtEIN3 directly binds to and activates ethyleneinduced ripening genes (63).

Botrytis cinerea, the causal agent of gray mold and other diseases, has more than 200 host plants, including apple. Ethylene contributes to foliar resistance of $A$. thaliana to $B$. cinerea. AtEIN2, a membrane-bound central regulator of ethylene signaling, acts upstream of AtEIN3 and is required for resistance of $A$. thaliana to $B$. cinerea $(4,69)$. Constitutive overexpression of AtERF1 in A. thaliana activates expression of pathogenesis-related proteins and enhances resistance to necrotrophic pathogens, including $B$. cinerea (7).

The objective of this study was to evaluate the potential contribution of ethylene to resistance of apple fruit to $B$. cinerea. Post-harvest ethylene production can be manipulated in climacteric fruit for long-term storage, making it important to understand the effects of ethylene on fruit defenses. We used a transgenic apple line co-suppressed for expression of 1-aminocyclopropane-1-carboxylic acid (ACC) synthase (ACS) (16) to study the influence of ethylene on pathogen defense. To determine the regulatory mechanism of ethylene-induced partial resistance in apple fruit, we cloned $B$. cinerea-inducible $E R F$ cDNAs and tested the expression of a GCC-box containing chitinase as a function of transient MdERF3 expression in Nicotiana benthamiana. 


\section{MATERIALS AND METHODS}

Biological materials and treatments. Apple (Malus domestica) 'Jonagold' fruits and leaves were obtained from Davis Farm, a commercial orchard in Corvallis, OR, for the sole purpose of cloning ERF coding and promoter sequences. To discover and clone pathogen-responsive MdERFs, three replicate fruit were subjected to one of three treatments: (i) propylene treatment, in which apple fruits in 19.8-liter jars were exposed to the humidified ethylene analogue propylene at $500 \mathrm{ppm}$, supplied at a flow rate of 45 to $60 \mathrm{ml} / \mathrm{min}$ for 1 or $3 \mathrm{~h}$ (2); (ii) $B$. cinerea treatment, consisting of 12 wounds inoculated with $1,000 \mathrm{~B}$. cinerea conidia per site and incubated in a moisture chamber for 6 h, 1 day, or 3 days; or (iii) control, consisting of no treatment. Pooled fruit samples from each treatment were frozen and stored at $-80^{\circ} \mathrm{C}$.

The transgenic 'Greensleeves' (GS) apple line 130Y, co-suppressed for expression of ACS (16), was chosen because fruit ethylene concentrations in this line were very low at the stage when untransformed fruit start to lose chlorophyll. Nontransformed GS and transgenic $130 \mathrm{Y}$ fruit were harvested at the preclimacteric stage from an experimental orchard in Davis, CA, in 2005, 2006, and 2007. One biological replicate of pooled samples, containing three fruit each, was collected for gene expression studies by semiquantitative reverse-transcription polymerase chain reaction (RT-PCR) every 3 days after harvest in 2006 and by quantitative RT-PCR at 3, 6, 24, and $72 \mathrm{~h}$ after $B$. cinerea inoculation after 2 weeks of storage in 2007 . Tobacco $(N$. benthamiana) plants were grown in a greenhouse.

Fungal inoculation. $B$. cinerea strain B05.10 was cultured on potato dextrose agar (2). Fruit were punctured along the equator with the tip of a syringe and inoculated with a conidial suspension of $B$. cinerea strain B05.10 (1,000 conidia/inoculation) in water or mock inoculated with water as described (2). Diameters of visible lesions were measured daily using a caliper.

Ethylene measurement. The ethylene concentration of individual fruit was measured daily for 1 week using a gas chromatograph equipped with a flame-ionization detector (Hach-Carle series 400 AGC, Loveland, CO) as described (2).

Cloning of MdERFs and chitinase cDNA and promoter sequences. Total RNA was extracted from three pooled apple fruit at each indicated time as described (6). Total RNA from each time point was combined: $1.5 \mu \mathrm{g}$ from each of two propylene treatments and $1.0 \mu \mathrm{g}$ from each of three $B$. cinerea treatments for a total of $3 \mu \mathrm{g}$ per treatment type. A first-strand cDNA synthesis kit (GE Healthcare, Piscataway, NJ) was used.

For initial cloning of MdERFs, degenerate primers (Supplementary Table S1) were designed to amplify the AP2/ERF domain based on sequences of A. thaliana, Lycopersicon esculentum, M. domestica, Oryza sativa, Vitis amurensis, and Cucumis sativus from GenBank using the CODEHOP algorithm (bioinformatics.weizmann.ac.il/blocks/codehop.html). All MdERF PCR products had the same size of $142 \mathrm{bp}$ after amplification of cDNA using touchdown PCR. Amplification conditions were 1 cycle at $94^{\circ} \mathrm{C}$ for $3 \mathrm{~min} ; 7$ cycles at $94^{\circ} \mathrm{C}$ for $30 \mathrm{~s}, 63$ to $57^{\circ} \mathrm{C}$ for $1 \mathrm{~min}$ $\left(1^{\circ} \mathrm{C}\right.$ decrease per cycle), and $72^{\circ} \mathrm{C}$ for $1 \mathrm{~min} ; 28$ cycles at $94^{\circ} \mathrm{C}$ for $30 \mathrm{~s}, 56^{\circ} \mathrm{C}$ for $1 \mathrm{~min}$, and $72^{\circ} \mathrm{C}$ for $1 \mathrm{~min}$; followed by a final extension at $72^{\circ} \mathrm{C}$ for $7 \mathrm{~min}$.

Amplification products were fractionated by electrophoresis in $2 \%$ NuSieve GTG agarose gels (BMA, Rockland, ME). The most intense band was excised, placed in a dialysis bag, and electroeluted from the gel using a horizontal electrophoresis chamber. Eluted DNA was extracted with phenol/chloroform and precipitated using ethanol and sodium acetate (58).

Purified PCR products were ligated using a pGEM-T Easy Vector (Promega Corp., Madison, WI) and transformed into competent Escherichia coli strain JM109. Recombinant plasmid DNA containing PCR products was purified using a Qiaprep spin miniprep kit (Qiagen, Valencia, CA) and inserts were sequenced. In total, 16, 42, and 56 clones were sequenced for control, propylene-treated, and $B$. cinerea-infected samples, respectively. DNA was sequenced using the T7 forward and SP6 reverse primer on an Applied Biosystems (Carlsbad, CA) Big Dye Terminator chemistry at Gene Gateway (Hayward, CA) or at the Center for Gene Research and Biotechnology, Oregon State University (Corvallis).

Expressed sequence clones of AP2/ERF domains that appeared more than twice following $B$. cinerea infection or propylene treatment were used to design primers for rapid amplification of cDNA ends (RACE). Both 3'- and 5'-end cDNA clones were obtained by RACE using the FirstChoice RLM-RACE kit (Ambion, Austin, TX) with gene-specific outer and inner primers designed from each expressed sequence clone (Supplementary Table S1). Nested PCR was performed with gene-specific outer and inner primers. The 5'-end of chitinase was obtained using gene-specific outer and inner primers based on a partial chitinase sequence (accession number AF494397). Cloning and sequencing was as described above. For confirmation, full-length cDNAs were amplified by PCR and sequenced. Open reading frame (ORF) was determined using the ORF finder program of the National Center for Biotechnology Information (http://www.ncbi.nlm.nih.gov/ projects/gorf/).

Phylogenetic analyses. ERF cDNA sequences were entered into the program BioEdit (www.mbio.ncsu.edu/bioedit/bioedit. $\mathrm{html}$ ) for conversion into deduced amino acid sequences. Amino acid sequences from apple and Arabidopsis were aligned using Clustal W. This alignment was converted back to nucleotide sequences using the program BioEdit. The aligned nucleotide sequences were used to generate a parsimony tree using PHYLIP (22) Specifically, SEQBOOT was used to generate 100 bootstrapped data sets. DNAPARS was used to generate trees from the 100 data sets. Finally, CONSENSE was used to generate the majority-rule consensus tree containing bootstrap values. The numbering system for AtERF genes is based on a recent classification (46).

Semiquantitative RT-PCR and quantitative RT-PCR. Total RNA $(5 \mu \mathrm{g})$ was extracted from one biological tissue sample from three pooled apple fruit from $A C S$-silenced line $130 \mathrm{Y}$ (16) or from untransformed GS as described (6). Potential genomic DNA contaminants were removed by digesting total RNA with FPLCpure RNase-free DNase (Amersham Bioscience, Piscataway, NJ) for $10 \mathrm{~min}$ at $37^{\circ} \mathrm{C}$. The enzyme was inactivated at $65^{\circ} \mathrm{C}$ for 10 min. Apple cDNAs were synthesized with oligo-dT using a first-strand cDNA synthesis kit (GE Healthcare). Semiquantitative RT-PCR was done to check the expression of disease-related genes such as lipoxygenase $(L O X)$ and polygalacturonase inhibitor protein (PGIP) and ACS1 expression in transgenic and nontransgenic fruit but quantitative RT-PCR was used to study $M d E R F$ expression in transgenic and nontransgenic apple. Glyceraldehyde 3-phosphate dehydrogenase (GAPDH) (CN494000) was used as an internal control (17) for equal loading and for constitutive expression in both semiquantitative and quantitative RT-PCR.

Quantitative RT-PCR primers and TaqMan probes were designed using Primer Express software (Applied Biosystems, Foster City, CA). Nonconserved regions of AP2/ERF domains in both Arabidopsis and apple were used to distinguish each $E R F$ gene (46); sequence comparisons to AtERF genes increased specificity for individual $M d E R F$ genes (i.e., unique sequences present in apple but not in Arabidopsis were used). The reporter dyes VIC and FAM were used for GAPDH and $M d E R F$, respectively, at the $5^{\prime}$ end. The nonfluorescent quencher MGB was used at the $3^{\prime}$ end. Quantitative RT-PCR was performed using an ABI Prism 7500 Sequence Detection System (Applied Biosystems, Foster City, CA). Standard thermal conditions were used: $50^{\circ} \mathrm{C}$ for $2 \mathrm{~min}$, $95^{\circ} \mathrm{C}$ for $10 \mathrm{~min}$, then 40 cycles of $95^{\circ} \mathrm{C}$ for $15 \mathrm{~s}$ and $60^{\circ} \mathrm{C}$ for 
$60 \mathrm{~s}$. Fluorescent signals were collected during the annealing and extension cycle. Cycle threshold $(\mathrm{Ct})$ values were determined using autothreshold. Relative expression $(\Delta \mathrm{Ct})$ of each cDNA sample was obtained by normalizing to the GAPDH transcript frequency. Relative mRNA expression was derived using $2^{-\Delta \Delta \mathrm{CT}}$, where $\Delta \Delta \mathrm{Ct}$ represents the $\Delta \mathrm{Ct}$ of a gene of interest minus the $\Delta \mathrm{Ct}$ at $0 \mathrm{~h}$ for each genotype (34). All values at $0 \mathrm{~h}$ were set to 1 . All samples were loaded in one 96-well plate for simultaneous comparison of all four MdERF genes and for testing amplification efficiencies of target and reference genes.

Isolation of promoter regions. Genomic DNA was extracted from Jonagold apple leaves (31). The 5'-upstream region of each $M d E R F$ gene was obtained using the Universal Genome Walker Kit (Clontech, Palo Alto, CA) according to the manufacturer's instructions with gene-specific primers. PCR-amplified DNA products were cloned and sequenced as described above. To verify each promoter sequence, a promoter-specific forward primer was designed for the predicted promoter region in combination with a reverse primer located in the ORF of the respective gene.

Promoter sequences were analyzed using the Signal Scan and Homology Search options of the database PLACE (http://www. dna.affrc.go.jp/PLACE/). TATA boxes were found using the neural network promoter prediction program from the Berkeley Drosophila genome project (http://www.fruitfly.org/seq_tools/ promoter.html).

Transient expression of MdERF3 in $N$. benthamiana. Binary plasmid with (pDU08.0313) or without (pDU99.2215) MdERF3 (21) was transferred to competent Agrobacterium tumefaciens strain EHA101 by heat shock. This vector contains an ampicillin resistance selectable marker gene and the entire coding region of MdERF3 between the CaMV35S promoter and the octopine synthase terminator cassette. Agrobacterium-mediated transient assays in $N$. benthamiana leaves were as described (35), with the following modifications. The concentration of the Agrobacterium suspension was adjusted to an optical density at $600 \mathrm{~nm}$ of 0.5 before infiltration. The Agrobacterium suspension was injected into the leaves using a 3-ml disposal syringe without a needle. Same-size circles (radius $=1 \mathrm{~cm}$ ) were drawn on leaves using a marker pen, and Agrobacterium suspension was injected until each circle were filled. Leaf color changed in the injected area, which allowed us to distinguish between injected and uninjected areas. The same leaf was inoculated at different sites with MdERF3-containing or empty vector. The experiment consisted of three biological replicates. Leaves were collected 1 day after infiltration. Intact leaves without infiltration were used as a control to determine effects of Agrobacterium infiltration on gene expression.

Total RNA ( $3 \mu \mathrm{g}$ ) was extracted from tobacco ( $N$. benthamiana) leaves using a phenol-based method (42). RNA was converted to cDNA using random hexamers for quantitative PCR analysis. Expression of MdERF3, Chn48, and 18S rRNA in N. benthamiana was analyzed using absolute quantification as recommended by Applied Biosystems (Foster City, CA). Mean values of three technical replicates of quantitative RT-PCR reactions of each sample were normalized to $18 \mathrm{~S}$ rRNA as an internal control. Standard curves for rRNA were generated using salmon sperm DNA with primers and probe for eukaryotic $18 \mathrm{~S}$ rRNA as the endogenous control (Applied Biosystems, Foster City, CA).

Statistical analyses. Data are presented as means \pm standard error. Area under disease progress curve (28) was used to determine the statistical significance of differences in lesion diameter after $B$. cinerea inoculation. The Mann-Whitney $U$ test was used to determine significant differences in lesion diameter after $B$. cinerea inoculation and in MdERF expression (SPSS, Chicago). Transient expression in $N$. benthamiana was analyzed using the Relative Expression Software Tool, considering three biological by three technical replicates (51). The significance threshold was $P=0.05$.

\section{RESULTS}

Effects of $A C S$ silencing on ethylene production and on susceptibility of apple fruit to $B$. cinerea. Suppression of $A C S$ in transgenic apple of line 130Y (16) inhibited endogenous ethylene biosynthesis in intact fruit (Fig. 1) and increased their susceptibility to B. cinerea relative to untransformed GS apple (Fig. 2). $A C S$-suppressed apple fruit lack the climacteric rise in ethylene biosynthesis (16). The magnitude of the genotype-dependent difference in ethylene biosynthesis was smaller immediately after harvest (Fig. 2A) than after incubation at room temperature for 2 weeks, during the climacteric peak (Fig. 2C). Whereas, right after harvest, ethylene production was <7-fold higher in untransformed than in $A C S$-suppressed apple fruit 7 days post inoculation, this difference in ethylene production was $\approx 60$-fold higher at the climacteric peak.

Ripening-related differences in ethylene biosynthesis and susceptibility to $B$. cinerea were correlated. The relative increase in lesion expansion between freshly harvested transgenic and untransformed apple fruit was not significant (Fig. 2B). However, the difference in lesion expansion between $A C S$-silenced and untransformed apple fruit became statistically significant when fruit were incubated at room temperature for 14 days prior to inoculation with $B$. cinerea (Fig. 2D). This trend was observed during three consecutive years (data not shown).

Cloning of fruit-expressed $M d E R F$ cDNAs. To investigate the role of $E R F$ genes in resistance of apple fruit to B. cinerea, MdERF genes were cloned from Jonagold apple fruit using RT-PCR with degenerate primers (Supplementary Figure S1A) designed to amplify AP2/ERF domains. The corresponding expressed sequence clones from initial PCR with degenerate primers were too short to be classified by similarity to previously defined $E R F$ subfamilies (46). Based on similarities of amino acid sequences, expressed sequence clones were classified into four defined groups which were different from previously defined subfamilies (46). Groups 1,2 , and 3 were identified in samples from fruit infected with $B$. cinerea or treated with the ethylene analog propylene. Except for group 1, expressed sequence clones were also identified in control fruit. Although the number of clones was limited, the two expressed sequence clones of group 4 were distinct because their amino acid sequences were not conserved around the third $\beta$-sheet.

Three full-length and one partial MdERF cDNAs were cloned from fruit tissue by RACE using primers designed from partial cDNA sequences (Fig. 3A; Supplementary Figure S1B). Each $M d E R F$ cDNA encodes a single AP2/ERF domain containing a predicted DNA-binding site. Similar to AtERF genes (46), each $M d E R F$ gene has conserved motifs of unknown function outside the AP2/ERF domain.

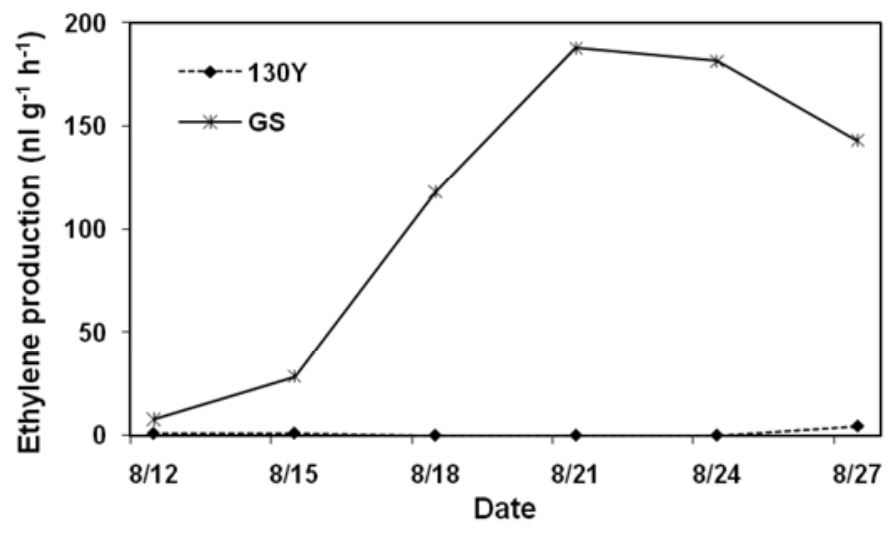

Fig. 1. Ethylene production in untransformed intact apple 'Greensleeves' (GS) and in 1-aminocyclopropane-1-carboxylic acid synthase $(A C S)$-suppressed fruit (130Y) after harvest. Dates indicate days after the harvest date, which was 11 August 2006. 
Phylogenetic comparison of the four $M d E R F$ coding sequences with all known Arabidopsis genes revealed clustering of MdERF4 and MdERF5 with AtERF genes from subfamilies 1 and 2a (46), respectively, while $M d E R F 3$ and $M d E R F 6$ were members of subfamily 10 (Fig. 3B). AtERF109, annotated as a member of subfamily 10 (46), did not cluster with subfamily 10 in our phylogenetic comparisons and, therefore, is not present in the figure. Detailed functional analysis of AtERF genes from these three subfamilies is lacking.

To check for the presence of introns, full-length ERFs were amplified from genomic DNA. Genomic amplification of MdERF4 (accession number JF412351) and MdERF5 (accession number JF412352) yielded no evidence of introns (data not shown), indicating that the gene structure has been conserved between apple and Arabidopsis. However, apple homologs of subfamily 10 were of particular interest because members of this subfamily contain introns in Arabidopsis (46). PCR was performed using genomic DNA to amplify MdERF3 (accession number JF412350) sequences surrounding the predicted intron site based on Arabidopsis subfamily 10. Amplification of genomic DNA with $M d E R F 3$-specific primers yielded a product that was $500 \mathrm{bp}$ larger than expected from the cDNA sequence. This product was sequenced and investigated for the presence of an intron. The Plant GDB GeneSeqer program of the Plant Genome Database (http://www.plantgdb.org/) identified an intron. Because the amplified sequence was not identical to $M d E R F 3$, this gene was named MdERF6 (accession number JF412353). The MdERF6 sequence lacked a stop codon. Our inability to amplify the corresponding region of MdERF3 using Taq polymerase without proofreading may indicate the presence of a large intron.

mRNA expression of $\boldsymbol{M d E R F}$. Semiquantitative RT-PCR of $G A P D H$ and ACS1 showed that ACS1 was expressed in untransformed but not in $A C S$-silenced apple (Supplementary Figure S2). ACS1 expression was strongly induced $3 \mathrm{~h}$ after wounding. ACS1 mRNA was barely detectable 6 and $24 \mathrm{~h}$ after wounding but increased after $72 \mathrm{~h}$. ACS1 was gradually induced during $B$. cinerea invasion, peaking $72 \mathrm{~h}$ after inoculation.

Quantitative RT-PCR showed that expression of all four $M d E R F$ genes was reduced in $A C S$-silenced relative to untransformed apple (Fig. 4). Expression of MdERF4, -5, and -6 was suppressed in transgenic fruit. In contrast, $M d E R F 3$, in particular, was induced, albeit to a reduced degree, in $A C S$-silenced apple. Therefore, wound- and pathogen-induced expression of MdERF3 is only partially dependent on ethylene biosynthesis.

Expression of MdERF4, -5, and -6 in untransformed GS apple fruit was highly induced $3 \mathrm{~h}$ after wounding, mimicking ACS1 expression. In contrast, all four MdERF genes and ACSI were expressed at a low level 3 and $6 \mathrm{~h}$ after inoculation of untransformed GS fruit with $B$. cinerea, suggesting that this pathogen suppresses the rapid wound-related induction of ethylene biosynthesis and signaling.

MdERF promoter sequence analysis. Partial cloning of MdERF3, -4, -5, and -6 promoter regions revealed 706, 778, 877, and 583 bp of upstream sequences, respectively. All four pro-

\section{Inoculation}

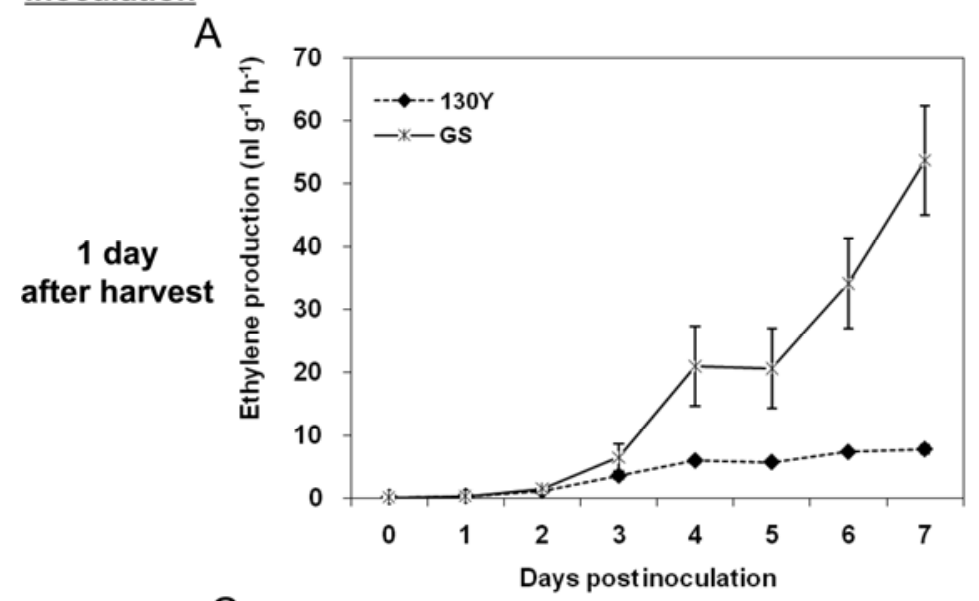

C

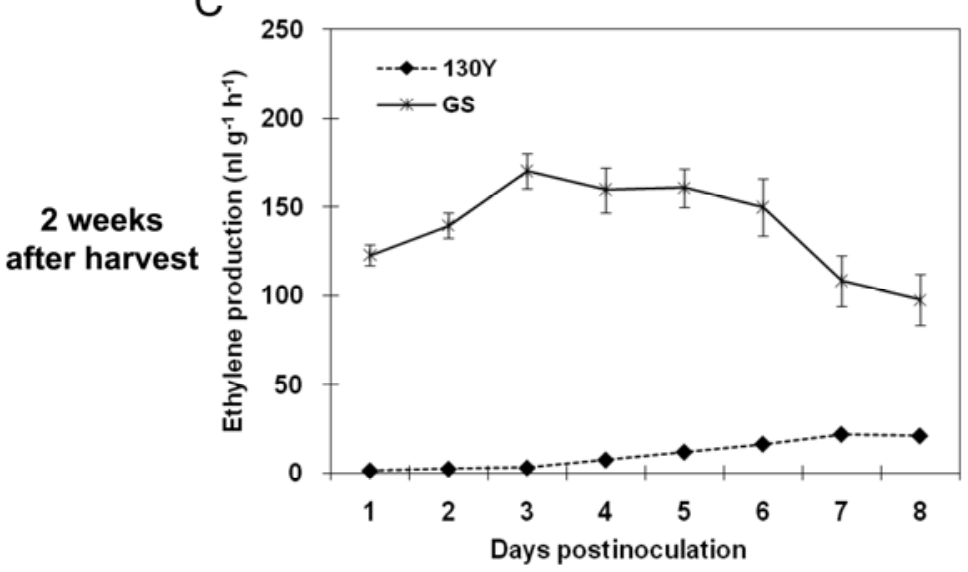

B

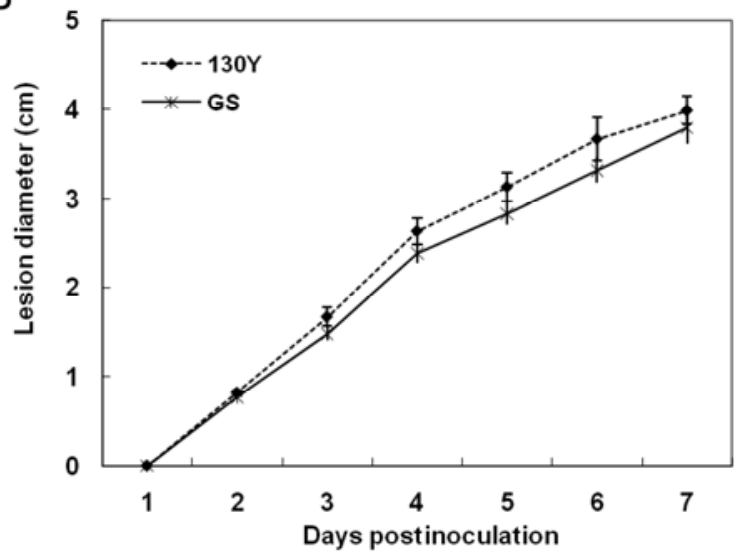

D

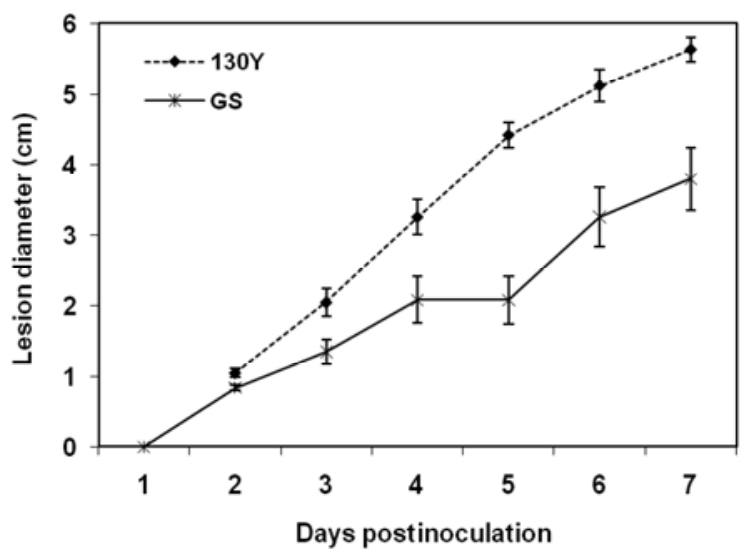

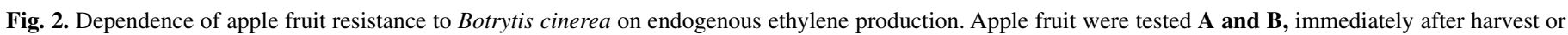

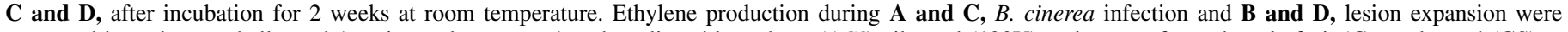

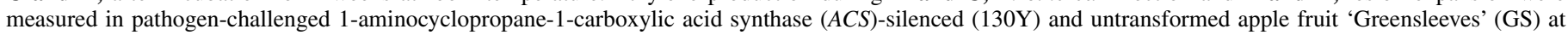

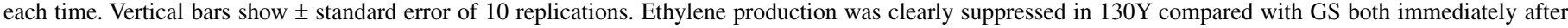

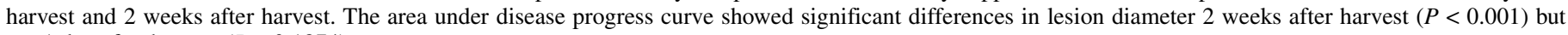
not 1 day after harvest $(P=0.1874)$. 
moter regions were analyzed for putative cis-acting regulatory elements (26). Three criteria were used to select cis-elements: (i) motifs were located on the plus strand upstream of the predicted transcriptional start site; (ii) motifs were at least five nucleotides long; and (iii) motifs related to plant hormone, pathogen, or stress responses were chosen (Table 1; Supplementary Figure S4). A summary of the motifs found in promoter regions of MdERF3, -4, -5 , and -6 is shown in Table 1 .
A

MdERF3

(Subfamily 10)

MdERF4

(Subfamily1)

MdERF5

(Subfamily 2a)

MdERF6

(Subfamily 10)
AP2/ERF domain
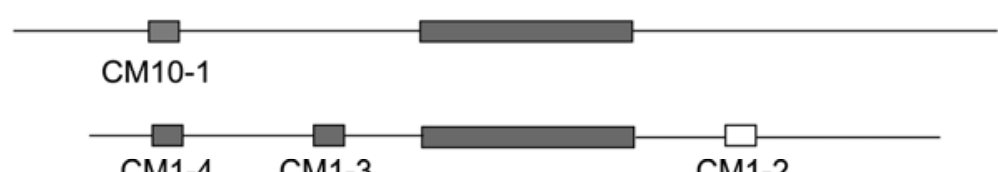

CM1-2

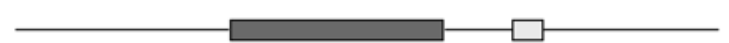

CM2-1

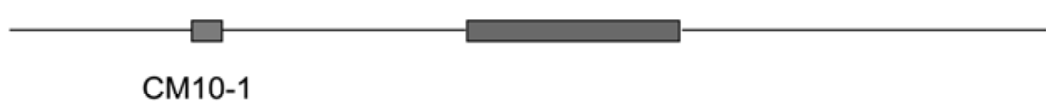

Size of predicted protein sequence

472 A.A.

323 A.A.

160 A.A.

405 A.A.

B

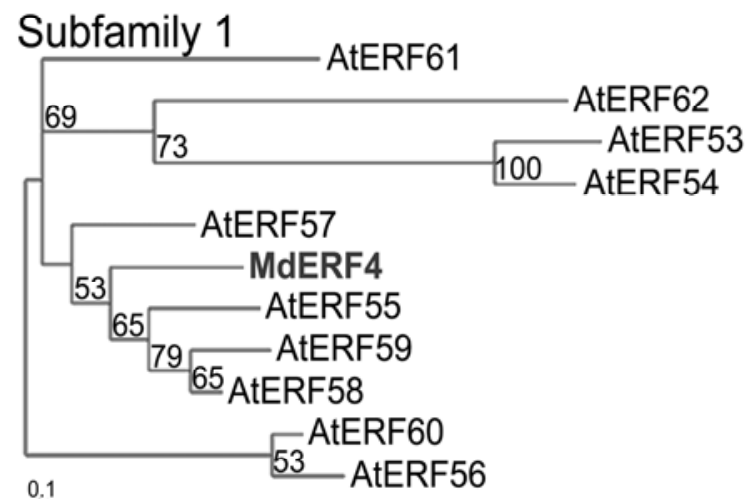

Subfamily $2 \mathrm{a}$
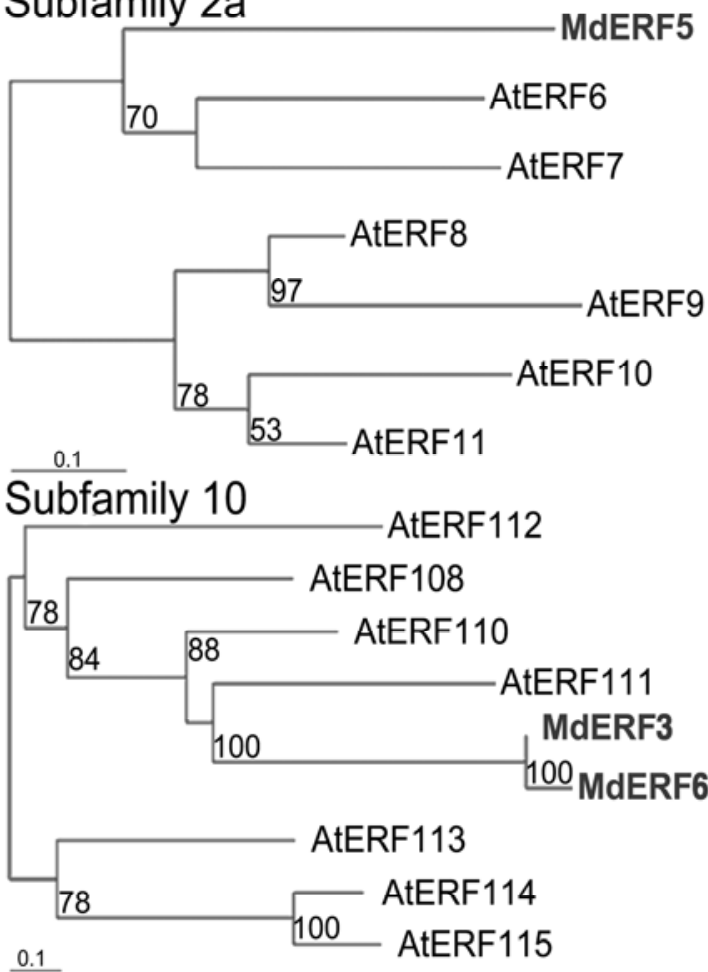

Fig. 3. Identification of Malus domestica ethylene response factor (MdERF) genes expressed in apple fruit 'Jonagold'. A, Diagrams of predicted amino acid sequences of MdERFs belonging to subfamilies 1, 2a, and 10. Subfamilies shown in parentheses and conserved motifs (CMs) are based on classifications of genomic ERF sequences from rice and Arabidopsis (46). A.A. = amino acids. MdERF6 shows a partial coding sequence. B, Three clades of a phylogenetic comparison of $122 A t E R F$ and four $M d E R F$ genes. Clades of the most parsimonious tree are shown together with percentages of 100 bootstrap replicates. 
Consensus sequences of cis-acting elements related to hormonal, abiotic, or biotic stress responses were found in all four promoters. The AtEIN3-binding site (63), an important cis-element related to ethylene signaling, was found in promoters of $M d E R F 3$,
-5, and -6 (Supplementary Figure S3). Upstream sequences of MdERF5 and -6 contained an additional ethylene-responsive element (ERE). TGA, a bZIP family TF (18), and MYB TF-binding sites were common features of all four MdERF genes.
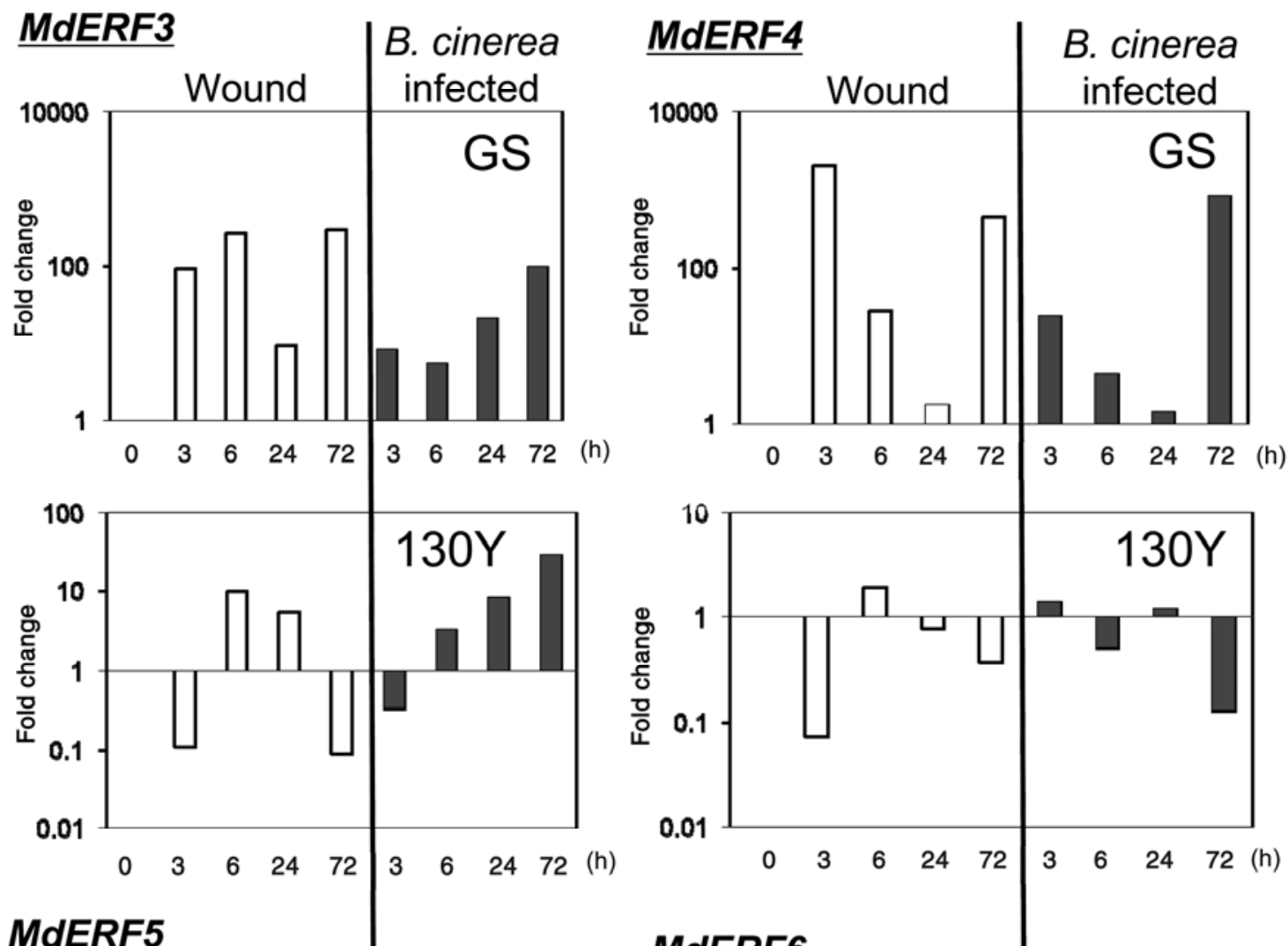

\section{MdERF5}

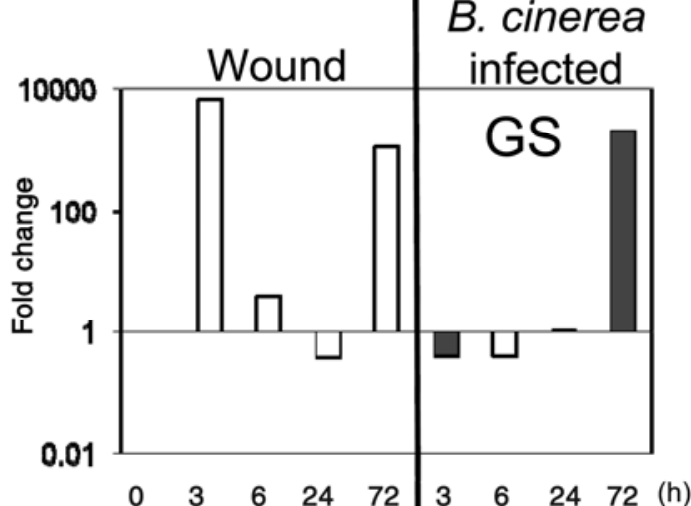

MdERF6
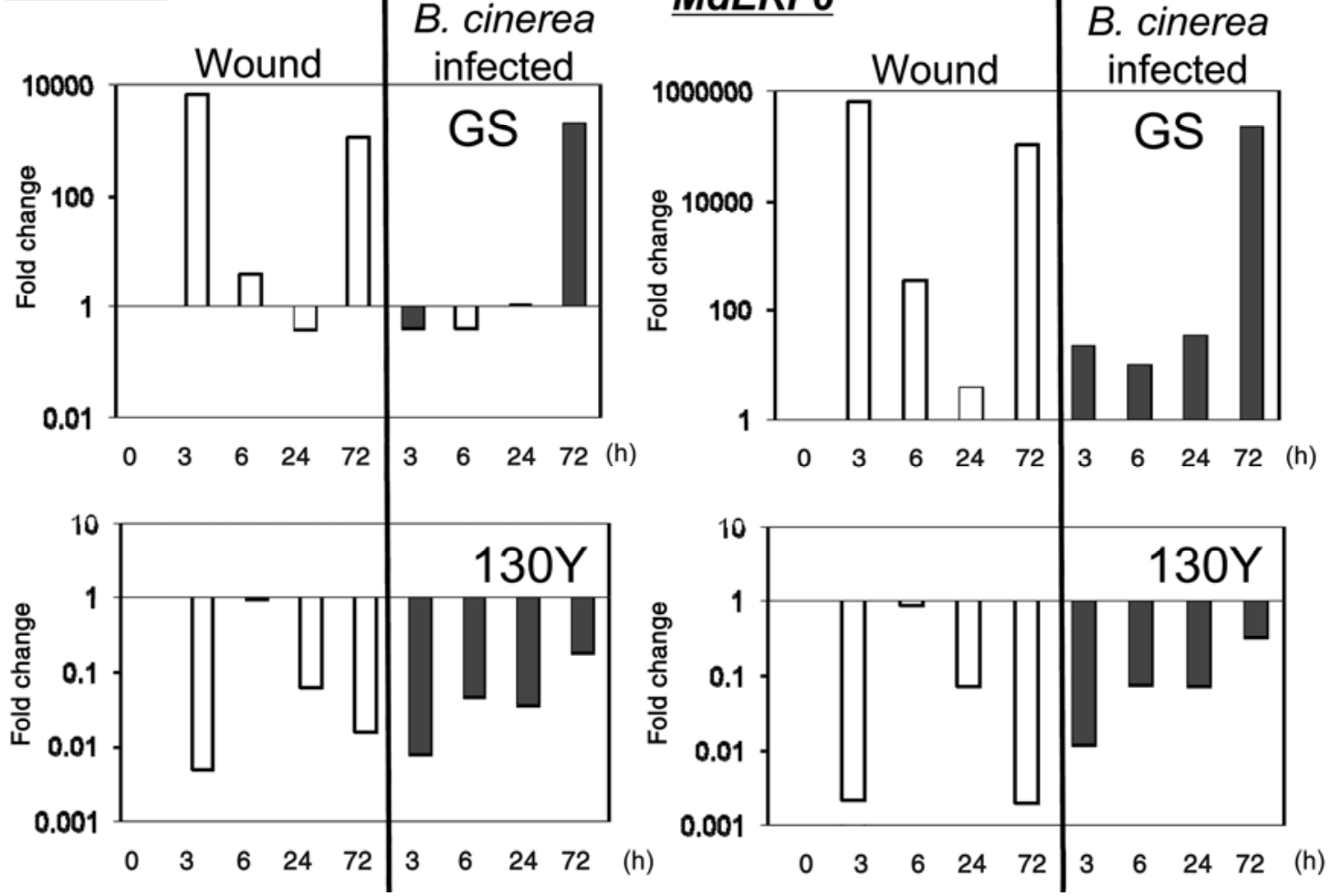

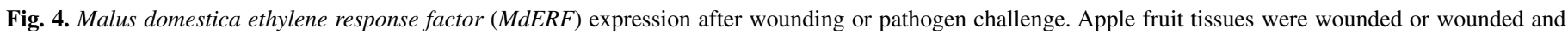

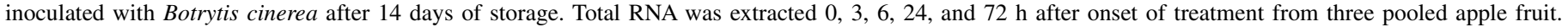

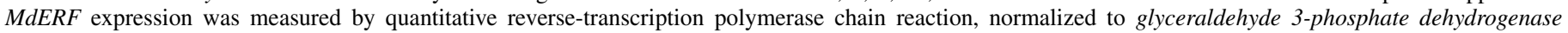

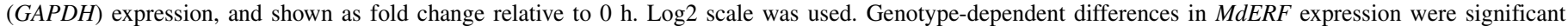

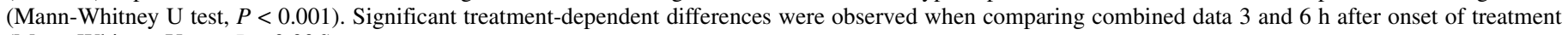
(Mann-Whitney U test, $P=0.006$ ). 
Uniquely, three BELL-type homeodomain TF-binding sites were identified in the MdERF3 promoter. WRKY TF-binding site Wboxes and a wound-activating region are exclusive to MdERF4. All MdERF genes contained drought-responsive cis-elements but different genes contained distinct motifs. Although MdERF4 and -5 had ABA-responsive elements, MdERF3 and -6 had dehydration-responsive elements.

Activation of chitinase mRNA expression by MdERF3. $M d E R F 3$ was the only one of four MdERF genes induced in ACSsilenced apple by wounding and B. cinerea infection (Fig. 4). Therefore, the effect of MdERF3 on expression of the downstream gene $C h n 48$ was tested in $N$. benthamiana after transient expression of MdERF3 using Agrobacterium infiltration. One day after Agrobacterium infiltration, MdERF3 mRNA expression was clearly elevated relative to the empty vector control (Table 2). In parallel, mRNA expression of the chitinase gene Chn48 (60) significantly $(P=0.016)$ increased in leaves that expressed $M d E R F 3$ relative to leaves that were treated with the empty vector control. An increase in Chn48 expression was also observed after Agrobacterium infiltration with an empty vector construct relative to unchallenged leaves, suggesting that this chitinase gene responds to either wounding or Agrobacterium spp. We did not infiltrate without Agrobacterium spp. and, therefore, cannot distinguish between these two possibilities.

\section{DISCUSSION}

Ethylene limits expansion of lesions caused by $\boldsymbol{B}$. cinerea in ripening apple fruit. Two lines of evidence illustrate that ethylene is necessary for induction of defenses against $B$. cinerea in apple fruit. First, $A C S$-suppressed apple fruit were more susceptible to $B$. cinerea (Fig. 2). Second, susceptibility increased in $A C S$-suppressed apple fruit with fruit ripening. $A C S$-suppressed fruit were slightly more susceptible to $B$. cinerea than untransformed apple immediately after harvest but this difference in susceptibility was much larger and statistically significant 14 days after harvest. Fruit did not produce ethylene immediately after harvest but ethylene biosynthesis reached its climacteric peak 14 days after harvest. Thus, activation of ethylene biosynthesis prior to inoculation is necessary to induce resistance against $B$. cinerea, implicating ripening-related ethylene production in priming of defense responses against $B$. cinerea (14). Our findings are compatible with ethylene's enhancement of resistance to B. cinerea in Arabidopsis spp. (7,69). Although genetic modification of the ethylene signal transduction pathway has not yet been accomplished in apple, results analogous to Arabidopsis were obtained using genetic suppression of ethylene biosynthesis.

The hypothesis that ethylene induces a defense against $B$. cinerea in Pyrus communis (pear) fruit has been tested previously

TABLE 1. Putative cis-acting elements in $M d E R F$ promoters $^{\mathrm{a}}$

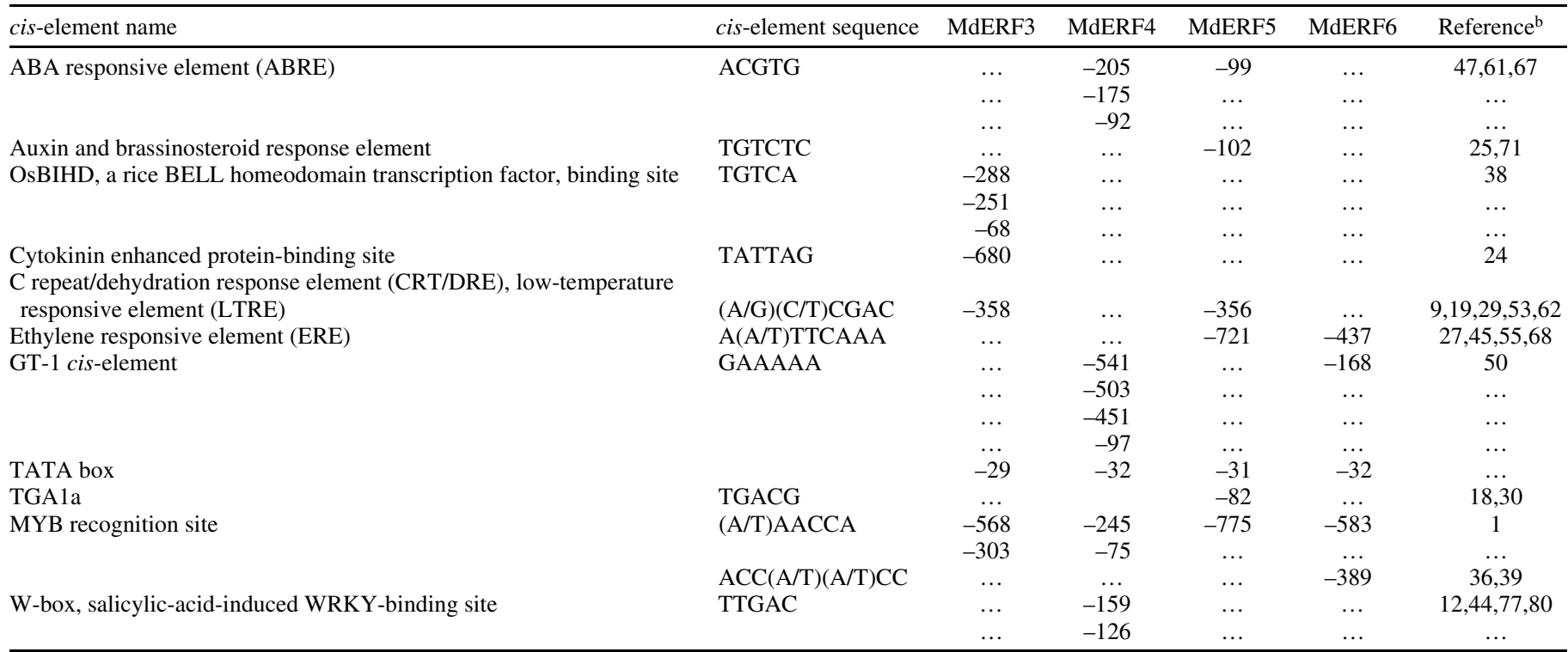

${ }^{a}$ Sizes of cloned MdERF3, $-4,-5$, and -6 promoter regions were 706, 778, 877, and 583 bp, respectively. Signal Scan Search options of the PLACE program were used to identify cis-elements. Numbers indicate locations of motifs relative to the predicted transcription start site at +1 .

${ }^{b}$ References are original reports of cis-elements or subsequent notes of other genes or other plant species.

TABLE 2. Quantitative polymerase chain reaction results after Agrobacterium-mediated transient expression of MdERF3 in tobacco leaves ${ }^{\mathrm{a}}$

\begin{tabular}{lccccc}
\hline Treatment & MdERF3 & Chn48 & rRNA & ERF/rRNA & Chn48/rRNA \\
\hline Vector with MdERF3 & 3.11 & 124.89 & 1.67 & 1.86 & 1.82 \\
& 35.86 & 228.86 & 19.66 & 0.39 & 1.64 \\
Vector without MdERF3 & 13.32 & 83.95 & 33.88 & 0.04 & 0.10 \\
& 0.23 & 25.58 & 4.40 & 0.02 & 4.74 \\
Unchallenged control & 4.58 & 196.78 & 32.30 & 0.01 & 1.31 \\
& 0.61 & 1.53 & 36.10 & 0.01 & 0.03 \\
& 0.41 & 1.63 & 37.97 & 0.03 & 0.12 \\
\hline
\end{tabular}

${ }^{a}$ Each value is the mean of three technical replicates. Each line in each treatment represents a biological replicate.

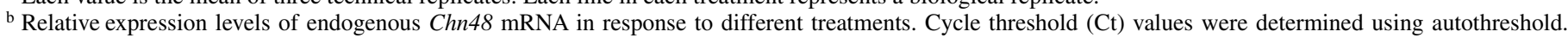
Relative expression $(\Delta \mathrm{Ct})$ of each cDNA sample was obtained by normalizing to the $18 \mathrm{~S}$ ribosomal RNA frequency. Statistical analysis using the Relative Expression Software Tool algorithm (51) revealed a significant difference in Chn48 expression between MdERF3-transfected samples and empty vector controls $(P=0.016)$ 
using exogenous application of chemicals to accelerate or inhibit ethylene biosynthesis, because no transgenic or mutant pear fruit with defects in ethylene production or signal transduction were available (2). Although effects of ethylene on disease resistance of pear fruit were small, inhibition of ethylene through binding of 1-methylcyclopropene (1-MCP) to the ethylene receptor in pear fruit resulted in a statistically significant increase in susceptibility to $B$. cinerea (2). By comparison, data presented here on endogenous suppression of ethylene biosynthesis in apple fruit showed a stronger and clearer increase in susceptibility to $B$. cinerea than that caused by exogenous manipulation of ethylene action in pear fruit. In contrast to plants, cultured $B$. cinerea produces ethylene in a 2-keto-4-methylbutyric acid-dependent manner $(11,15)$. Ethylene production in $A C S$-silenced fruit was higher during $B$. cinerea infection (Fig. 2) than during fruit ripening (Fig. 1), suggesting that the fungus may produce ethylene in vivo. Previous comparison of 1-MCP- and aminoethoxyvinylglycinesensitive ACC and ethylene production during $B$. cinerea infection of pear fruit provides evidence for microbial ethylene production (2). Therefore, it is an intriguing possibility that ethylene produced by $B$. cinerea triggers defense responses in apple fruit, although the contribution of oligosaccharide elicitors cannot be ruled out (10). If so, fungal ethylene production might be a disadvantage for infecting $B$. cinerea.

The expression of several ethylene- and defense-related genes during fruit ripening was tested by semiquantitative RT-PCR. Only the expression of ACS1 correlated with climacteric ethylene production in apple fruit (Supplementary Figure S4). PGIP mRNA was expressed in healthy apple fruit, as previously reported (79). Although PGIP is regulated independently of ethylene, it is strongly induced in response to $B$. cinerea infection (79).

Regulation of MdERF expression. MdERF3 was the only gene observed by quantitative RT-PCR to be induced by $B$.

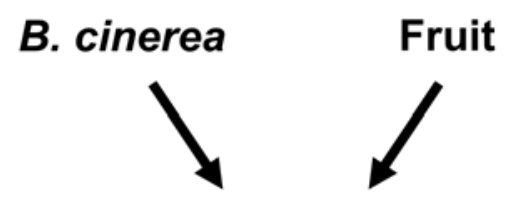

Ethylene

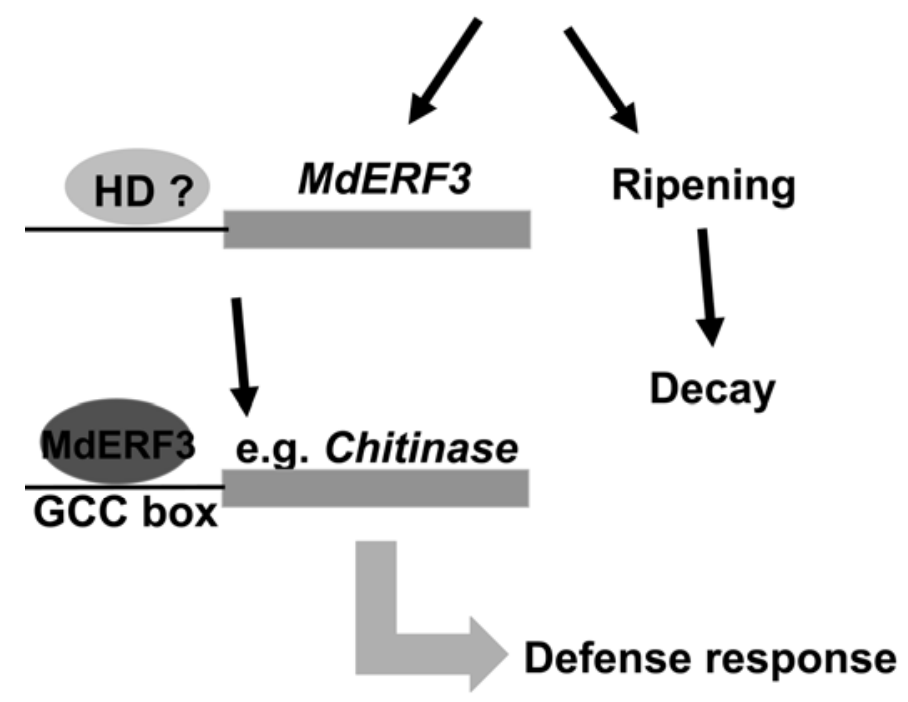

Fig. 5. Proposed role of ethylene during Botrytis cinerea infection of apple fruit. The model depicts a portion of the signal cascade that activates defense responses and fruit ripening. Ethylene was produced by the fruit and may be produced by $B$. cinerea. Homeodomain transcription factors (HD) may activate expression of Malus domestica ethylene response factor 3 (MdERF3). MdERF3 may bind to the GCC box and activate expression of defense-related genes such as chitinase. cinerea infection in $A C S$-silenced apple fruit (Fig. 4). Interestingly, the sequences of MdERF3 and MdERF6 are very closely related (Fig. 3A and B) but the response of MdERF6 to B. cinerea was entirely ethylene dependent, suggesting that important pathogen-responsive regulatory sequence elements may be lacking in the MdERF6 promoter or that biological replication was not sufficient to detect differences in the response of MdERF6.

In contrast to MdERF3, expression of MdERF4, -5, and -6 appeared to be ethylene dependent. Therefore, regulation of $M d E R F 3$ is similar to MdERF1, the expression of which increases with apple fruit ripening (73). MdERF1 expression was not completely suppressed by 1-MCP treatment during fruit ripening, suggesting ethylene-independent regulation of this gene (73).

The transient, wound-induced expression of MdERF4, -5, and - 6 genes and ACS1 appeared to be suppressed in B. cinereachallenged apple fruit. Unlike nonpathogenic bacterial species, Erwinia betavasculorum also suppresses wound-related ethylene production in Solanum tuberosum (potato) (33). It remains to be determined whether suppression of wound-related ethylene production is required for pathogenicity. Transcription of all MdERF genes and ACS1 appeared to increase 3 days after wounding of apple fruit. This might be a response to wounding, ripening, placement of apple fruit into a closed moisture chamber, or accumulation of ethylene in the chamber. A flow-through system allowing for exchange of air inside the box would have eliminated the latter possibility.

Putative cis-elements in $\boldsymbol{M d E R F}$ promoters. Although we did not conduct functional analysis of promoter regions, the putative TF-binding sites identified here are indicative of the differential $M d E R F$ expression observed. Cis-elements are typically located within $1 \mathrm{~kb}$ upstream of the translation start site in Arabidopsis (41). The four $M d E R F$ promoter sequences analyzed were $\approx 500$ to $900 \mathrm{bp}$ long, too short for complete description of $M d E R F$ promoters.

AtEIN3 binds to and activates expression of AtERF1 in response to ethylene signaling in Arabidopsis (63). Promoter sequences of $M d E R F 3,-5$, and -6 contain putative EIN3-binding sites. Although the MdERF4 gene did not contain a putative EIN3-binding site in its predicted promoter region, such a site was found between the predicted transcriptional initiation site and the translational start codon ATG (data not shown).

Two types of EREs exist. The A(A/T)TTCAAA motif is found in promoters of the fruit-specific L. esculentum (tomato) gene E4 (45) and senescence-related carnation gene GST1 (27). The second ERE is the GCC-box but this box is not present in promoters of fruit ripening or flower petal senescence genes (49). Ethylene may regulate MdERF5 and -6 during fruit ripening, because both genes contain A(A/T)TTCAAA motifs. GCC-boxes in the promoter of $N t E R F 3$ ( $N$. tabacum) are apparently needed for its autorepression (48). There was no evidence for GCC-boxes among the limited promoter sequence information for any of the four MdERF genes.

Three BIHD cis-elements known to bind to the BELL-type homeobox protein (named after the distinctive Bell domain) from $O$. sativa (rice) (38) were found exclusively in the $M d E R F 3$ promoter. In contrast to the function of this gene family in animal development (5), none of the homeodomain (HD)-containing TFs from plants exert homeotic effects. The HD superfamily is classified into six groups based on HD size, location, and association with other domains (5). BIHD is an important cis-element activated by $B$. cinerea. The OVEREXPRESSIOR OF CATIONIC PEROXIDASE 3 (OCP3) mutant with a defect in a homeodomaincontaining gene enhances jasmonate-dependent resistance to the necrotrophic pathogens $B$. cinerea and Plectosphaerella cucumerina, while interactions with biotrophic pathogens such as the oomycete Hyaloperonospora parasitica and the bacterium Pseudomonas syringae pv. tomato DC3000 remain unaffected (13). $O C P 3$ is expressed at a very low level in healthy plants but 
its expression further decreases during Plectosphaerella cucumerina infection (13). The OCP3 gene is different from other classes of homeodomain genes such as the knotted-related homeobox (KNOTTEDl) and the homeodomain associated to a leucine zipper (HD-Zip) (13). The HD-Zip type homeobox gene H52 in L. esculentum (tomato) limits spread of programmed cell death (43). In addition, Arabidopsis and Petroselinum crispum (parsley) homeodomains associated with finger domain (PHDtype homeodomain) proteins bind to and regulate $P R 2$ expression (32), suggesting that HD-containing TFs play an important role in induced resistance to plant pathogens.

MdERF3 regulates chitinase expression. To identify potential target genes containing cis-elements important for their induced expression, MdERF3 was transiently expressed in tobacco and chitinase $C h n 48$ expression was measured by quantitative RTPCR. Chn 48 is known to be induced by ethylene; its promoter contains GCC-boxes, a motif necessary for transcriptional activation of pathogenesis-related genes regulated by ethylene (60). Expression of the chitinase $C h n 48$ significantly increased after transient expression of MdERF3 (Table 2). These data show that the chitinase promoter is a possible target of MdERF3. Transgenic tobacco plants expressing endochitinase from Trichoderma harzianum are highly resistant to $B$. cinerea (37). Moreover, transgenic Fragaria $\times$ ananassa (strawberry) plants expressing the chitinase gene ch5 from Phaseolus vulgaris are also highly resistant to $B$. cinerea but not to the anthracnose pathogen Colletotrichum acutatum (72). Therefore, it is possible that ethylene-dependent induction of chitinase in apple fruit could contribute to inhibiting growth of B. cinerea (Fig. 5).

\section{ACKNOWLEDGMENTS}

We thank S. L. Uratsu (Department of Plant Sciences, University of California, Davis) for making the binary vector containing MdERF3, E. Hood (Washington University, St. Louis) for distribution of the $A$. tumefaciens strain EHA101, A. I. Prokhnevsky (Department of Botany and Plant Pathology, Oregon State University) and Z. Jeknic (Department of Horticulture, Oregon State University) for helping with Agrobacterium infiltration, and M. L. Mendum (University of California, Davis) for assistance in editing the manuscript.

\section{LITERATURE CITED}

1. Abe, H., Urao, T., Ito, T., Seki, M., Shinozaki, K., and YamaguchiShinozaki, K. 2003. Arabidopsis AtMYC2 (bHLH) and AtMYB2 (MYB) function as transcriptional activators in abscisic acid signaling. Plant Cell 15:63-78.

2. Akagi, A., and Stotz, H. U. 2007. Effects of pathogen polygalacturonase, ethylene, and firmness on interactions between pear fruits and Botrytis cinerea. Plant Dis. 91:1337-1344.

3. Allen, M. D., Yamasaki, K., Ohme-Takagi, Tateno, M., and Suzuki, M. 1998. A novel mode of DNA recognition by a $\beta$-sheet revealed by the solution structure of the GCC-box binding domain in complex with DNA. EMBO J. 17:5484-5496.

4. Alonso, J. M., Hirayama, T., Roman, G., Nourizadeh, S., and Ecker, J. R. 1999. EIN2, a bifunctional transducer of ethylene and stress responses in Arabidopsis. Science 284:2148-2152.

5. Ariel, F. D., Manavella, P. A., Dezar, C. A., and Chan, R. L. 2007. The true story of the HD-Zip family. Trends Plant Sci. 12:419-426.

6. Asif, M., Trivedi, P., Solomos, T., and Tucker, M. 2006. Isolation of highquality RNA from apple (Malus domestica) fruit. J. Agric. Food Chem. 54:5227-5229.

7. Berrocal-Lobo, M., Molina, A., and Solano, R. 2002. Constitutive expression of ETHYLENE-RESPONSE-FACTOR1 in Arabidopsis confers resistance to several necrotrophic fungi. Plant J. 29:23-32.

8. Brown, R. L., Kazan, K., McGrath, K. C., Maclean, D. J., and Manners, J. M. 2003. A role for the GCC-box in jasmonate-mediated activation of the PDF1.2 gene of Arabidopsis. Plant Physiol. 132:1020-1032.

9. Busk, P. K., Jensen, A. B., and Pages, M. 1997. Regulatory elements in vivo in the promoter of the abscisic acid responsive gene rabl7 from maize. Plant J.11:1285-1295.

10. Campbell, A. D., and Labavitch, J. M. 1991. Induction and regulation of ethylene biosynthesis and ripening by pectic oligomers in tomato pericarp discs. Plant Physiol. 97:706-713.

11. Chague, V., Elad, Y., Barakat, R., Tudzynski, P., and Sharon, A. 2002. Ethylene biosynthesis in Botrytis cinerea. FEMS Microbiol. Ecol. 40:143149.

12. Chen, C., and Chen, Z. 2002. Potentiation of developmentally regulated plant defense response by AtWARKY18, a pathogen-induced Arabidopsis transcription factor. Plant Physiol. 129:706-716.

13. Coego, A., Ramirez, V., Gil, M. J., Flors, V., Mauch-Mani, B., and Vera, P. 2005. An Arabidopsis homeodomain transcription factor, OVEREXPRESSOR OF CATIONIC PEROXIDASE 3, mediates resistance to infection by necrotrophic pathogens. Plant Cell 17:2123-2137.

14. Conrath, U., Beckers, G. J. M., Flors, V., Garcia-Agustin, P., Jakab, G., Mauch, F., Newman, M. A., Pieterse, C. M. J., Poinssot, B., Pozo, M. J., Pugin, A., Schaffrath, U., Ton, J., Wendehenne, D., Zimmerli, L., and Mauch-Mani. B. 2006. Priming: Getting ready for battle. Mol. PlantMicrobe Interact. 19:1062-1071.

15. Cristescu, S. M., D. De Martinis, te Lintel Hekkert, S., Parker, D. H., and Harren, F. J. M. 2002. Ethylene production by Botrytis cinerea in vitro and in tomatoes. Appl. Environ. Microbiol. 68:5342-5350.

16. Dandekar, A., M., Teo, G., Defilippi, B. G., Uratsu, S. L., Passey, A. J., Kader, A. A., Stow, J. R., Colgan, R., J., and James, D. J. 2004. Effect of down-regulation of ethylene biosynthesis on fruit flavor complex in apple fruit. Transgenic Res. 13:373-384.

17. Defilippi, B. G., Kader, A. A., and Dandekar, A. M. 2005. Apple aroma: Alcohol acyltransferase, a rate-limiting step for ester biosynthesis, is regulated by ethylene. Plant Sci. 168:1199-1210.

18. Despres, C., Chubak, C., Rochon, A., Clark, A., Bethune, T., Desveaux, D., and Fobert, P. R. 2003. The Arabidopsis NPR1 disease resistance protein is a novel cofactor that confers redox regulation of DNA binding activity to the basic domain/leucine zipper transcription factor TGA1. Plant Cell 15:2181-2191.

19. Dubouzet, J. G., Sakuma, Y., Ito, Y., Kasuga, M., Dubouzet, E. G., Miura, S., Seki, M. Shinozaki, K., and Yamaguchi-Shinozaki, K. 2003. OsDREB genes in rice, Oryza sativa L., encode transcription activators that function in drought-, high-salt- and cold-responsive gene expression. Plant J. 33:751-763.

20. Elliott, K. A., and Shirsat, A. H. 1998. Promoter regions of the extA extensin gene from Brassica napus control activation in response to wounding and tensile stress. Plant Mol. Biol. 37:675-687.

21. Escobar, M. A., Civerolo, E. L., Summerfelt, K. R., and Dandekar., A. M. 2001. RNAi-mediated oncogene silencing confers resistance to crown gall tumorigenesis. Proc. Natl. Acad. Sci. USA 98:13437-13442.

22. Felsenstein, J. 1989. PHYLIP-Phylogeny Inference Package (version 3.2). Cladistics 5:164-166

23. Fujimoto, S. Y., Ohta, M., Usui, A., Shinshi, H., and Ohme-Takagi., M. 2000. Arabidopsis ethylene-responsive element binding factors act as transcriptional activators or repressors of GCC box-mediated gene expression. Plant Cell 12:393-404.

24. Fusada, N., Masuda, T., Kuroda, H., Shimada, H., Ohta, H., and Takamiya, K. 2005. Identification of novel cis-element exhibiting cytokinin-dependent protein binding in vitro in the $5^{\prime}$-region of NADPHprotochlorophyllide oxidoreductase gene in cucumber. Plant Mol. Biol. 59:631-645.

25. Goda, H., Sawa, S., Asami, T., Fujioka, S., Shimada, Y., and Yoshida, S. 2004. Comprehensive comparison of auxin-regulated and brassinosteroidregulated genes in Arabidopsis. Plant Physiol. 134:1555-1573.

26. Higo, K., Ugawa, Y., Iwamoto, M., and Korenaga, T. 1999. Plant cisacting regulatory DNA elements (PLACE) database. Nucleic Acid Res. 27:297-300

27. Itzhaki, H., Maxson, J. M., and Woodson, W. R. 1994. An ethyleneresponsive element is involved in the senescence-related expression of the carnation glutathione-S-transferase (GST1) gene. Proc. Natl. Acad. Sci. USA 91:8925-8929.

28. Jeger, M. J., and Viljanen-Rollinson, S. L. H. 2001. The use of the area under the disease-progress curve (AUDPC) to assess quantitative disease resistance in crop cultivars. Theor. Appl. Genet. 102:32-40.

29. Jiang, C., Iu, B., and Singh, J. 1996. Requirement of a CCGAC cis-acting element for cold induction of the BN115 gene from winter Brassica napus. Plant Mol. Biol. 30:679-684.

30. Katagiri, F., Lam, E., and Chua, N.-H. 1989. Two tobacco DNA-binding proteins with homology to the nuclear factor CREB. Nature 340:727-730.

31. Kim, C. S., Lee, C. H., Shin, J. S., Chung, Y. S., and Hyung, N. I. 1997. A simple and rapid method for isolation of high quality genomic DNA from fruit trees and conifers using PVP. Nucleic Acids Res. 25:1085-1086.

32. Korfhage, U., Trezzini, G. F., Meier, I., Hahlbrock, K., and Somssich, I. E. 1994. Plant homeodomain protein involved in transcriptional regulation of pathogen defense-related gene. Plant Cell 6:695-708.

33. Kuykendall, L. D., and Hunter, W. J. 2008. Carbohydrate and ethane release with Erwinia carotovora subspecies betavasculorum-induced necrosis. Curr. Microbiol. 56:128-133. 
34. Livak, K.J., and Schmittgen, T. D. 2001. Analysis of relative gene expression data using real-time RT-PCR and the $2-\Delta \Delta \mathrm{ct}$ method. Methods 25:402-408.

35. Llave, C., Kasschau, K. D., and Carrington, J. C. 2000. Virus-encoded suppressor of posttranscriptional gene silencing targets a maintenance step in the silencing pathway. Proc. Natl. Acad. Sci. USA 97:1340113406.

36. Logemann, E., Parniske, M., and Hahlbrock, K. 1995. Modes of expression and common structural features of the complete phenylalanine ammonia-lyase gene family in parsley. Proc. Natl. Acad. Sci. USA 92:59055909.

37. Lorito, M., Woo, S. L., Fernandez, I. G., Colucci, G., Harman, G. E., Pintor-toro, J. A., Filppone, E., Muccifora, S., Lawrence, C. B., Zoina, A., Tuzun, S., and Scala, F. 1998. Genes from mycoparasitic fungi as a source for improving plant resistance to fungal pathogens. Proc. Natl. Acad. Sci. USA 95:7860-7865.

38. Luo, H., Song, F., Goodman, R. M., and Zheng, Z. 2005. Up-regulation of OsBIHD1, a rice gene encoding BELL homeodomain transcriptional factor, in disease resistance responses. Plant Biol. 7:459-468.

39. Maeda, K., Kimura, S., Demura, T., Takeda, J., and Ozeki, Y. 2005. DcMYB1 acts as a transcriptional activator of the carrot phenylalanine ammonia-lyase gene $(D c P A L 1)$ in response to elicitor treatment, UV-B irradiation and the dilution effect. Plant Mol. Biol. 59:739-752.

40. Magnani, E., Sjolander, K., and Hake, S. 2004. From endonucleases to transcription factors: Evolution of the AP2 DNA binding domain in plants. Plant Cell 16:2265-2277.

41. Maleck, K., Levine, A., Eulgem, T., Morgan, A., Schmid, J., Lawton, K. A. Dangl, J. L., and Dietrich, R. A. 2001. The transcriptome of Arabidopsis thaliana during systemic acquired resistance. Nat. Genet. 26:403-410.

42. Martin, R. C., Liu, P.-P., and Nonogaki, H. 2005. Simple purification of small RNAs from seeds and efficient detection of multiple microRNAs expressed in Arabidopsis thaliana and tomato (Lycopersicon esculentum) seeds. Seed Sci. Res. 15:319-328.

43. Mayda, E., Tornero, P., Conejero, V., and Vera, P. 1999. A tomato homeobox gene (HD-Zip) is involved in limiting the spread of programmed cell death. Plant J. 20:591-600.

44. Menke, F. L. H., Champion, A., Kijne, J. W., and Memelink, J. 1999. A novel jasmonate- and elicitor-responsive element in the periwinkle secondary metabolite biosynthetic gene Str interacts with a jasmonateand elicitor- inducible AP2-domain transcription factor, ORCA2. EMBO J. 18:4455-4463.

45. Montgomery, J., Goldman, S., Deikman, J., Margossian, L., and Fischer, R. L. 1993. Identification of an ethylene-responsive region in the promoter of a fruit ripening gene. Proc. Natl. Acad. Sci. USA 90:59395943.

46. Nakano, T., Suzuki, K., Fujimura, T., and Shinshi, H. 2006. Genome-wide analysis of the ERF gene family in Arabidopsis and rice. Plant Physiol. 140:411-432.

47. Nakashima, K., Fujita, Y., Katsura, K., Maruyama, K., Narusaka, Y., Seki, M., Shinozaki, K., and Yamaguchi-Shinozaki, K. 2006. Transcriptional regulation of $\mathrm{ABI} 3$ - and $\mathrm{ABA}$-responsive genes including $R D 29 B$ and RD29A in seeds, germinating embryos, and seedlings of Arabidopsis. Plant Mol. Biol. 60:51-68.

48. Nishiuchi, T., Shinshi, H., and Suzuki, K. 2004. Rapid and transient activation of transcription of the ERF3 gene by wounding in tobacco leaves. J. Biol. Chem. 279:55355-55361.

49. Ohme-Takagi, M., Suzuki, K., and Shinshi, H. 2000. Regulation of ethylene-induced transcription of defense genes. Plant Cell Physiol. 41:1187-1192.

50. Park, H. C., Kim, M. L., Kang, Y. H., Jeon, J. M., Yoo, J. H., Kim, M. C., Park, C. Y., Jeong, J. C., Moon, B. C., Lee, J. H., Yoon, H. W., Lee, S.-H., Chung, W. S., Lim, C. O., Lee, S. Y., Hong, J. C., and Cho, M. J. 2004. Pathogen- and $\mathrm{NaCl}$-induced expression of the SCaM-4 promoter is mediated in part by a CT-1 box that interacts with a GT-1-like transcription factor. Plant Physiol. 135:2150-2161.

51. Pfaffl, M. W., Horgan, G. W., and Dempfle, L. 2002. Relative expression software tool (REST) for group-wise comparison and statistical analysis of relative expression results in real-time PCR. Nucleic Acids Res. 30:e36.

52. Pirrello, J., Jaimes-Miranda, F., Sanchez-Ballesta, M. T., Tournier, B., Khalil-Ahmad, Q., Regad, F., Latche, A., Pech, J. C., and Bouzayen, M. 2006. Sl-ERF2, a tomato ethylene response factor involved in ethylene response and seed germination. Plant Cell Physiol. 47:1195-1205.

53. Qin, F., Sakuma, Y., Li, J., Liu, Q., Li, Y.-Q., Shinozaki, K., and Yamaguchi-Shinozaki, K. 2004. Cloning and functional analysis of a novel DREB1/CBF transcription factor involved in cold-responsive gene expression in Zea mays L. Plant Cell Physiol. 48:1042-1052.

54. Rashotte, A. M., Mason, M. G., Hutchison, C. E., Ferreira, F. J., Schaller, G. E., and Kieber, J. J. 2006. A subset of Arabidopsis AP2 transcription factors mediates cytokinin responses in concert with a two-component pathway. Proc. Natl. Acad. Sci. USA 103:11081-11085.

55. Rawat, R., Xu, Z.-F., Yao, K.-M., and Chye, M.-L. 2005. Identification of cis-elements for ethylene and circadian regulation of the Solanum melongena gene encoding cysteine proteinase. Plant Mol. Biol. 57:629643.

56. Riechmann, J. L., Heard, J., Martin, G., Reuber, L., Jiang, C.-Z., Keddir, J., Adam, L., Pineda, O., Ratcliffe, O. J., Samaha, R. R., Creelman, R., Pilgrim, M., Broun, P., Zhang, J. Z., Ghandehari, D., Sherman, B. K., and Yu, G.-L. 2000. Arabidopsis transcription factors: Genome-wide comparative analysis among eukaryotes. Science 290:2105-2110.

57. Sakuma, Y., Liu, Q., Dubouzet, J. G., Abe, H., Shinozaki, K., and Yamaguchi-Shinozaki, K. 2002. DNA-binding specificity of the ERF/AP2 domain of Arabidopsis DREBs, transcription factors involved in dehydration- and cold-inducible gene expression. Biochem. Biophys. Res. Commun. 290:998-1009.

58. Sambrook, J., Fritsch, E. F., and Maniatis, T. 1989. Molecular Cloning: A Laboratory Manual, 2nd ed. Cold Spring Harbor Laboratory Press, Cold Spring Harbor, NY.

59. Shen, Y. G., Zhang, W. K., He, S. J., Zhang, J. S., Liu, Q., and Chen, S. Y. 2003. An EREBP/AP2-type protein in Triticum aestivum was a DREbinding transcription factor induced by cold, dehydration and ABA stress. Theor. Appl. Genet.106:923-930.

60. Shinshi, H., Usami, S., and Ohme-Takagi, M. 1995. Identification of an ethylene-responsive region in the promoter of a tobacco class I chitinase gene. Plant Mol. Biol. 27:923-932.

61. Simpson, S. D., Nakashima, K., Narusaka, Y., Seki, M., Shinozaki, K., and Yamaguchi-Shinozaki, K. 2003. Two different novel cis-acting elements of erd1, a clpA homologous Arabidopsis gene function in induction by dehydration stress and dark-induced senescence. Plant $\mathrm{J}$. $33: 259-270$

62. Skinner, J. S., von Zitzewitz, J., Szucs, P., Marquez-Cedillo, L., Filichkin, T., Amundsen, K., Stockinger, E. J., Thomashow, M. F., Chen, T. H. H., and Hayes, P. M. 2005. Structural, functional, and phylogenetic characterization of a large $C B F$ gene family in barley. Plant Mol. Biol. 59:533551.

63. Solano, R., Stepanova, A., Chao, Q., and Ecker, J. R. 1998. Nuclear events in ethylene signaling: A transcriptional cascade mediated by ethylene-insensitive3 and ethylene-response-factor1. Genes Dev. 12:37033714.

64. Song, C.-P., Agarwal, M., Ohta, M., Guo, Y., Halfter, U., Wang, P., and Zhu, J.-K. 2005. Role of an Arabidopsis AP2/EREBP-type transcriptional repressor in abscisic acid and drought stress responses. Plant Cell 17:2384-2396.

65. Strompen, G., Gruner, R., and Pfitzner, U. M. 1998. An as-1-like motif controls the level of expression of the gene for the pathogenesis-related protein 1a from tobacco. Plant Mol. Biol. 37:871-883.

66. Suzuki, K., Suzuki, N., Ohme-Takagi, M., and Shinshi, H. 1998. Immediate early induction of mRNAs for ethylene-responsive transcription factors in tobacco leaf strips after cutting. Plant J. 15:657-665.

67. Suzuki, M., Ketterling, M. G., and McCarty, D. R. 2005. Quantitative statistical analysis of cis-regulatory sequences in ABA/VP1- and CBF/ DREB1-regulated genes of Arabidopsis. Plant Physiol. 139:437-447.

68. Tapia, G., Verdugo, I., Yanez, M., Ahumada, I., Theoduloz, C., Cordero, C., Poblete, F., Gonzlez, E., and Ruiz-Lara, S. 2005. Involvement of ethylene in stress-induced expression of the TLC1.1 retrotransposon from Lycopersicon chilense Dun. Plant Physiol. 138:2075-2086.

69. Thomma, B. P., Eggermont, K., Tierens, K. F., and Broekaert, W. F. 1999. Requirement of functional ethylene-insensitive 2 gene for efficient resistance of Arabidopsis to infection by Botrytis cinerea. Plant Physiol. 121:1093-1102.

70. Tournier, B., Sanchez-Ballesta, M., T., Jones, B., Pesquet, E., Regad, F., Latche, A., Pech, J.-C., and Bouzayen, M. 2003. New members of the tomato ERF family show specific expression pattern and diverse DNAbinding capacity to the GCC box element. FEBS Lett. 550:149-154.

71. Ulmasov, T., Murfett, J., Hagen, G., and Guilfoyle, T. J. 1997. Aux/IAA proteins repress expression of reporter genes containing natural and highly active synthetic auxin response elements. Plant Cell 9:1963-1971.

72. Vellicce, G. R., Diaz Ricci, J. C., Hernandez, L., and Castagnaro, A. P. 2006. Enhanced resistance to Botrytis cinerea mediated by the transgenic expression of the chitinase gene $c h 5 B$ in strawberry. Transgenic Res. 15:57-68.

73. Wang, A., Tan, D., Tkahashi, A., Zhong, T., and Harada, T. 2007. MdERFs, two ethylene response factors involved in apple fruit ripening. J. Exp. Bot. 58:3743-3748.

74. Wang, K, L., C., Li, H., and Ecker, J. R. 2002. Ethylene biosynthesis and signaling networks. Plant Cell 14:S131-S151.

75. Wei, G., Pan, Y., Lei, J., and Zhu, Y.-X. 2005. Molecular cloning, phylogenetic analysis, expressional profiling and in vitro studies of TINY2 from Arabidopsis thaliana. J. Biochem. Mol. Biol. 38:440-446. 
76. Wu, L., Chen, X., Ren, H., Zhang, Z., Zhang, H., Wang, J., Wang, X.-C., and Huang, R. 2007. ERF protein JERF1 that transcriptionally modulates the expression of abscisic acid biosynthesis-related gene enhances the tolerance under salinity and cold in tobacco. Planta 226:815-825.

77. Xu, K., Xu, X., Fukao, T., Canlas, P., Maghirang-Rodriguez, R., Heuer, S., Ismail, A. M., Bailey-Serres, J., Ronald, P. C., and Mackill, D. J. 2006. SublA is an ethylene-response-factor-like gene that confers submergence tolerance to rice. Nature 442:705-708.

78. Yang, Z., Tian, L., Latoszek-Green, M., Brown, D., and Wu, K. 2005.
Arabidopsis ERF4 is a transcriptional repressor capable of modulating ethylene and abscisic acid responses. Plant Mol. Biol. 58:585-596.

79. Yao, C, Conway, W. S., Ren, R., Smith, D., Ross, G. S., and Sams, C. E. 1999. Gene encoding polygalacturonase inhibitor in apple fruit is developmentally regulated and activated by wounding and fungal infection. Plant Mol. Biol. 39:1231-1241.

80. Yu, D., Chen, C., and Chen, Z. 2001. Evidence for an important role of WRKY DNA binding proteins in the regulation of NPR1 gene expression. Plant Cell 13:1527-1539.

\section{Erratum}

Corrections were made to Figure $3 \mathrm{~B}$ on page 1315. Changes to this article were made on November 2, 2011. 